\title{
Growing Season Vegetation Dynamics Based on NDVI and the Driving Forces in Nepal during 1982-2015
}

\author{
Binod Baniya ${ }^{1,2,3 *}$, Qiuhong Tang1,2, Madan Koirala4, \\ Kedar Rijal ${ }^{4}$ and Giri Kattel ${ }^{5}$
}

\begin{abstract}
Monitoring and attributing growing season vegetation dynamics have become crucial for maintaining the structure and function of the ecosystem. The objective of this research was to examine the spatial and temporal vegetation changes and explore their driving forces during growing season in Nepal. It also explored the variation of Normalized Difference Vegetation Index (NDVI) in different altitudes at each $100 \mathrm{~m}$ interval. The National Oceanic and Atmospheric Administration (NOAA) NDVI, monthly temperature, precipitation and Shuttle Radar Topography Mission (SRTM) 90m Digital Elevation Model (DEM) were used. The linear regression model, Sen's slope, Mann Kendall test and Pearson correlation between NDVI and climate, i.e., temperature and precipitation were computed. The driving forces were identified based on threshold segmentation method. Our results showed positive intensity of vegetation change. The NDVI has significantly increased at the rate of $0.001 \mathrm{yr}^{-1}, 0.0005 \mathrm{yr}^{-1}$ and $0.002 \mathrm{yr}^{-1}$ in growing season, spring and autumn but it has insignificantly increased at the rate of $0.0003 \mathrm{yr}^{-1}$ in summer. In the meantime, growing season temperature has significantly increased with an average warming trend of $0.03^{\circ} \mathrm{Cyr}^{-1}$ but precipitation decreased at the rate of 2.76 $\mathrm{mm} \mathrm{yr}^{-1}$ during 1982-2015. The NDVI increased in $84.20 \%$ (53.08\% significant) of the area. The correlation between NDVI and temperature was found positive whereas correlation with precipitation was negative. Spatially, $84.05 \%$ of the study area found positive correlation between NDVI and temperature with $25.72 \%$ significance $(p<0.05)$ which was very less with precipitation. Our results demonstrate that NDVI was strongly correlated with temperature compared with precipitation. Beyond the climate, NDVI changes were also attributed to multi-control environments and ecological restoration in Nepal.
\end{abstract}

Key words: NDVI; growing season; climate; driving forces; Nepal

Baniya, B., Q. Tang, M. Koirala, K. Rijal, and G. Kattel. 2020: Growing Season Vegetation Dynamics Based on NDVI and the Driving Forces in Nepal during 19822015 No. 17: page 1 to 22. DOI: https://doi.org/10.3126/forestry.v17i0.33619

1 Land Surface Processes and Global Change Research Group, Institute of Geographical Sciences and Natural Resources Research, Chinese Academy of Sciences, Beijing, China

2 University of Chinese Academy of Sciences (UCAS), Beijing, China

3 Department of Environmental Science, Patan Multiple Campus, Tribhuvan University, Nepal

4 Central Department of Environmental Science, Tribhuvan Universiy, Nepal

5 The University of Melbourne, Victoria, VIC 3010, Australia

* Correspondence: bbaniya@cdes.edu.np 


\section{Introduction}

Growing season vegetation change is an important indicator of ecosystem dynamics and climate change (Walther et al. 2002) which is contributed by vegetation changes in spring (April, May), summer (June, July, August) and autumn (September, October) season (Zhou et al. 2001; Piao et al. 2011). The response of vegetation dynamics to climate change has become a crucial issue in global change research (Piao et al. 2006; Park and Sohn 2010; Piao et al. 2011; Wang et al. 2011; Schut et al. 2015). The beginning, end and duration of growing season are strongly indicated by climatic factors such as temperature (Vitasse et al. 2011) and precipitation (Craine et al. 2011; Shen et al. 2015). In turn, growing season vegetation change can exert important influences on the hydrological cycle through alteration of surface radiation, temperature, energy exchange and terrestrial carbon uptake (Myneni et al. 1997; Schaefer et al. 2005; Bonan 2008; Jeong et al. 2011). Therefore, there are important linkages between change in growing season vegetation and climate. Satellite measurements of the normalized difference vegetation indexes (NDVI) have been widely used to understand growing season vegetation change in large spatial scales (Myneni et al. 1997; Zhou et al. 2001; Jeong et al. 2009). NDVI has also been used to assess the effect of climate change on biomass, productivity and photosynthetic activity during growing season in many terrestrial ecosystems. It has been found that the maximum NDVI values over a year are correlated with species richness (Pettorelli et al. 2005) suggesting that the beginning, end and duration of the growing season and timing of the annual maximum NDVI are also relevant for the wildlife habitat, reproduction and migration. Studies suggest that the recent climate change has been a dominant contributor to increased greenery in $28.4 \%$ of the global vegetated areas (Zhu et al. 2016). The positive effects of climate change come from higher temperature that enhances photosynthesis and lengthens the growing season. Such changing vegetation dynamics due to climate change is particularly important in regions with high topographic and climate gradients. Field data are generally difficult to be used for predicting such vegetation dynamics at national, regional or global scales because such data are traditionally collected and used over relatively small spatial and temporal scales.

As discussed above, a large body of literature exists on the use of NDVI to detect changes in vegetation growing season and linking the changes to climate changes; however, such studies are scarce in Nepal. The intensity and rhythm of the Asian monsoon is changing significantly due to climate change (IPCC 2007). Consequently, erratic rainfall events, increase in dry periods, floods, land slide, forest fire, glacier retreats and glacial lake outburst floods are exacerbating the problems in vegetation productivity and ecosystem services (Karki et al. 2017). Beyond climatic factors, increasing human activities due to socio-economic growth, urbanization (i.e. total urban population is $38.26 \%$ with $6 \%$ annual growth rate) (CBS 2011), cropland expansion, deforestation, increased grazing, transhumance activities and ecological restoration are also accelerating the widespread changes in land use types and vegetation system that are disturbed unevenly in different geographic regions 
(DoFRS 2017). Therefore, there is an urgent need to understand how vegetation dynamics is changing in response to environment. There is an increasing interest in understanding the changing vegetation dynamics in Nepal; however, most of the previous studies follow same pattern of examining tree-ring growth (Chhetri and Cairns 2016; Gaire et al. 2017a; Gaire et al. 2017b; Kharal et al. 2017; Shrestha et al. 2017; Thapa et al. 2017; Tiwari et al. 2017b). These studies are also highly site and species-specific and use quadrates in small spatial scale dealing only with a single mechanism of vegetation dynamics and climate change. There were very few studies related to NDVI in this region. Among them, mapping and attributing NDVI showed positive NDVI trends and attributed primarily due to $\mathrm{CO}_{2}$ level in Nepal (Krakauer et al. 2017). Similarly, spatial and temporal variation of NDVI and its implication for carbon dynamics were identified from 1982-2015 (Baniya et al. 2018) which found positive NDVI and carbon trends in Nepal. This study showed that increased NDVI was more sensitive to the temperature. The significant increasing NDVI trends were observed during summer over the Koshi River Basin (Zhang et al. 2013). However, growing season vegetation dynamics and the driving forces in Nepal still remain scarce and poorly understood at the country scale which is very important to manage physical, biological and socio-economic environment in Nepal.

In this study, the long-term growing season vegetation changes and environmental drivers were examined using satellite measured NDVI and in situ climatic data for the period of 1982-2015. The vegetation changes were derived in each $100 \mathrm{~m}$ altitude based on $90 \mathrm{~m}$ DEM data sets of Nepal. The main objective of this study is to evaluate the long term growing season vegetation change and explore their driving forces. Specifically, this study aims to understand the spatial and temporal evolution of the growing season vegetation changes and vegetation changes in each $100 \mathrm{~m}$ altitude. It finds the role of climatic and non-climatic (i.e. ecological restoration, multi-environmental controls and anomalous degradation) factors in intensity and magnitude of the vegetation changes. For the temporal trend analysis, we considered the vegetation in forest, shrub lands, grassland and crop lands (Stibig et al. 2007; Wang et al. 2017) where the average NDVI values are more than 0.1. The annual average NDVI less than 0.1 was masked out because GIMMS NDVI ranges between 0.2 and 0.1 represent snow/glacier, water bodies, deserts, built-up areas, exposed soils and barren lands (Zhou et al. 2001). Spatially, this study covered entire the country for spatial mapping and the trends analysis.

\section{Materials and Methods}

\section{Study Area}

Nepal, located between $26^{\circ} 22^{\prime}$ and $30^{\circ} 27^{\prime} \mathrm{N}$ and $80^{\circ} 04^{\prime}$ and $88^{\circ} 12^{\prime} \mathrm{E}$ in the central part of the Himalayan region is characterized by unique topography and climatic variations. The altitude varies from $70 \mathrm{~m}$ above sea level in southern low lands to $8,848 \mathrm{~m}$ at the Mount Everest in the north. Based on this altitudinal variation, Nepal has been divided in to 6 bioclimatic zones ranging from broad leaved forest in the tropical climatic zone below $1000 \mathrm{~m}$ altitude to alpine forest and nival zone above 
5000m altitude (Dobremez 1976; LRMP 1986). The major vegetated lands are forest (39.1\%), cultivated lands (29.83\%), shrub lands $(3.40 \%)$ and grasslands $(7.90 \%)$ (Uddin et al. 2015) (Figure 1).

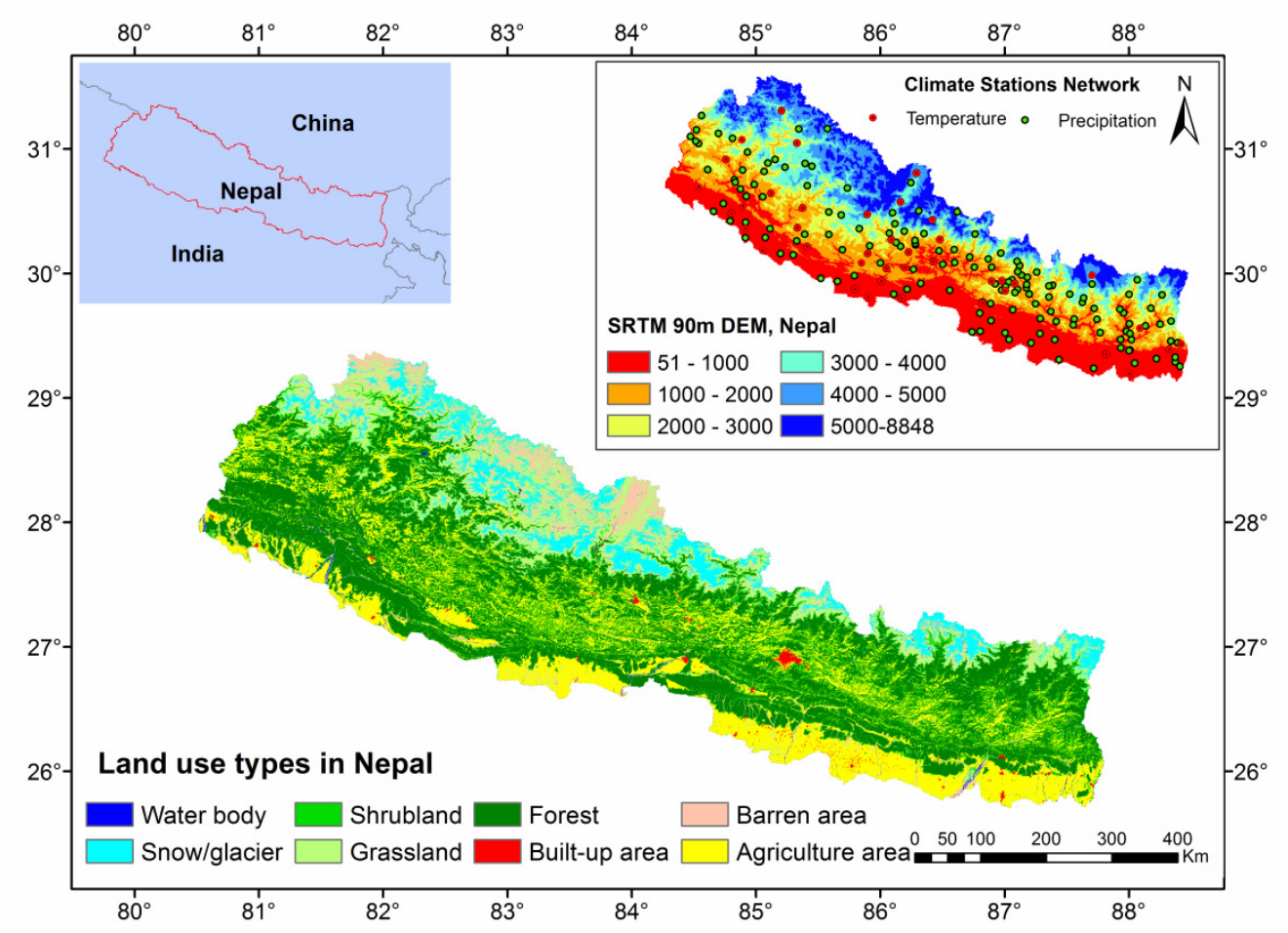

Figure 1: The study areas with land use land cover types and $\operatorname{DEM}(\mathrm{m})$ in Nepal

The left inset map shows the geographical location of Nepal and the right inset map shows the location of climate station

The annual precipitation ranges from $200 \mathrm{~mm}$ in parts of the northern Himalaya regions to $5,500 \mathrm{~mm}$ in the south with a national average of $1800 \mathrm{~mm}$ and average temperature can be as high as $30^{\circ} \mathrm{C}$ in south and as low as $-10^{\circ} \mathrm{C}$ in north (DHM 2015). The climate of Nepal is characterized by four distinct seasons, i.e., premonsoon, monsoon, post-monsoon and winter season and the growing season begins in spring and ends in autumn overlapping with the monsoon season. The forests are further categorized into needle-leaved closed forest $(9.47 \%)$, needle-leaved open forest $(5.62 \%)$, broad-leaved closed forest $(14.40 \%)$ and broad-leaved open forest $(9.61 \%)$ (Uddin et al. 2015). In general, Abies spectabilis, Betula utilis, Pinus wallichiana, Rhododendron campanulatum, Juniperus indica are the major treeline species in the Nepal Himalaya. In middle hills, dominant species are hill Sal, Schimacastanopsis and Chir pine. Similarly, in lower part, tropical Sal and mixed broadleaved, riverine broad-leaved and riverine Khair and Sisoo forests are dominant. 
Above the treeline, there are alpine meadow, pasture, trans-himalayan scrubs, dwarf rhododendron scrubs, alpine mats and scrubs in thick layers (MENRIS/ICIMOD 2008)

\section{NOAA NDVI 3g.v1 Data}

The original NDVI data sets were generated from NOAA's Advanced Very High Resolution Radiometer (AVHRR) sensors under the framework of Global Inventory Monitoring and Modeling System (GIMMS). The GIMMS NDVI data product spanning from 1982 to 2015 was downloaded from https://ecocast.arc.nasa.gov/data/pub/gimms/3g.v1. The data were corrected for calibration, view geometry, volcanic aerosols and other effects. It has the temporal resolution of 15 days and the spatial resolution of $8 \mathrm{~km}$. The monthly NDVI data were composited by using maximum value composite methods (Holben 1986).

\section{Climatic Data}

The ground-based observations of monthly air temperature and precipitation data for the period of 1982-2015 were obtained from the Department of Hydrology and Meteorology, Nepal. We used the data only for the months during the growing season (April-October). We used monthly rainfall data from 174 meteorological stations and maximum and minimum air surface temperature data from 40 meteorological stations as shown in Figure 1. Only the data available from meteorological stations since 1982 were considered for the analysis. For the altitude, NASA Shuttle Radar Topographic Mission (SRTM) 90m Digital Elevation Data (DEM), version-4 available as 3 arc second from the site of USGS were used.

\section{Methods}

Growing season mean NDVI, linear slope and intensity of vegetation dynamics were computed using time series of NDVI data. To obtain a better understanding of seasonal contribution, the growing season of Nepal was divided into spring (AprilMay), summer (June-August) and autumn (Sep-Oct) seasons (Piao et al. 2011). The linear slope, Sen's slope (Sen 1968) and Mann Kendall test (Kendall 1975; Mann 1945) were applied for both NDVI and climate, i.e., temperature and precipitation. The temporal and spatial NDVI patterns were also examined in different altitudes using raster NDVI and SRTM 90m DEM. Similarly, the average annual temperature and precipitation during growing season were computed using monthly data sets. Then, monthly precipitation and temperature data in each station were rasterized at $8 \mathrm{~km}$ spatial resolution and made similar grid with NDVI data. The Kriging interpolation was used (Oliver and Kriging 1990; Ding et al. 2007; Peng et al. 2011) to prepare the spatial data sets of climates and used for the correlation study with NDVI.

\section{GS-NDVI Trends}

The linear regression slope estimated by regression model indicated the mean temporal change of NDVI while positive slope indicates increasing and negative 
slope indicates decreasing trends (Piao et al. 2011; Fensholt and Proud 2012; Liu et al. 2015).

$$
\text { Slope }=\frac{n \times \sum_{i=1}^{n} i \times N D V I_{i}-\sum_{i=1}^{n} i \sum_{i=1}^{n} N D V I_{i}}{n \times \sum_{i=1}^{n} i^{2}-\left(\sum_{i=1}^{n} i\right)^{2}}
$$

where, slope is the trend in the vegetation dynamics, $\mathrm{n}$ is the number of years in the study period, $i$ is the order of the year from 1982-2015, and $\mathrm{NDVI}_{\mathrm{i}}$ is the mean NDVI in the $i^{\text {th }}$ year.

A $t$-test (Zhang et al. 2011) in MATLAB was used for each pixel to analyze significant trend of the NDVI slope. In this study, we used Mann-Kendall test to evaluate the statistical significance of the trends (Mann 1945; Kendall 1975; Hirsch et al. 1982). The Sen's slope was also estimated to identify the magnitude of the trend (Sen 1968) which is based on the assumption of a linear trend (Gilbert 1987).

\section{Intensity of GS-NDVI Trends}

The intensity of the GS-NDVI was computed based on proxy anomaly $\sigma(\mathrm{i})$. It is defined as the standardized departure from the average growing season NDVI (Lotsch et al. 2005; Liu et al. 2015; Xu et al. 2015) during 1982-2015.

$$
\sigma(\mathrm{i})=\frac{\mathrm{NDVI}_{\mathrm{i}}-\mathrm{Mean}(\mathrm{NDVI})}{\mathrm{SD}(\mathrm{NDVI})}
$$

The proxy $\sigma(\mathrm{i})$ represents intensity of the vegetation dynamics, $\mathrm{NDVI}_{\mathrm{i}}$ is the average NDVI for year $i$, and mean and SD are the average and standard deviation of the NDVI for the period of 1982-2015, respectively. We used three standard deviation categories for both positive and negative changes: 1) $\sigma(\mathrm{i})<1$ indicates weak intensity; 2) $\sigma(i)>1$ referred to as the moderate intensity and 3) $\sigma(i)>2$ as large intensity.

\section{Correlation Analysis between GS-NDVI and Climate}

Pearson correlation coefficient between NDVI and climatic factors were used to identify climate change impact on vegetation dynamics. This approach has been widely applied to analyze the correlation between NDVI and climatic factors (Jiang et al. 2017; Pang et al. 2016; Sun and Qin 2016; Tian et al. 2015). Pearson correlation coefficient in each pixel was calculated using a built in function in MATLAB and a $t$ test (Zhang et al. 2011) was performed at each pixel for significant correlation analysis for the correlation between NDVI and climatic controls. If the $p$ value is less than the significance level of 0.05 , the correlation is statistically significant. 


\section{Driving Force Analysis}

The climatic and non-climatic drivers of vegetation changes were separated based on threshold segmentation method. In this method, we examined five categories of the driving force as developed by (Tian et al. 2015) using annual NDVI trend and NDVIclimate control correlation values. If NDVI and climatic factor is positively correlated and significant, then climate change is defined as the main driving force of vegetation activity. Ecological restoration programs are considered as main driving forces of the vegetation change if NDVI slope in each pixel is greater than mean NDVI slope of the whole study area. In this study, the threshold mean NDVI slope value of Nepal is 0.0009 . This mean NDVI slope is considered as the threshold value used to distinguish climate and non-climatic drivers. Here, the pixels which exhibit significant changes are only processed to identify driving forces and the five categories of driving forces are analyzed (Figure 2).

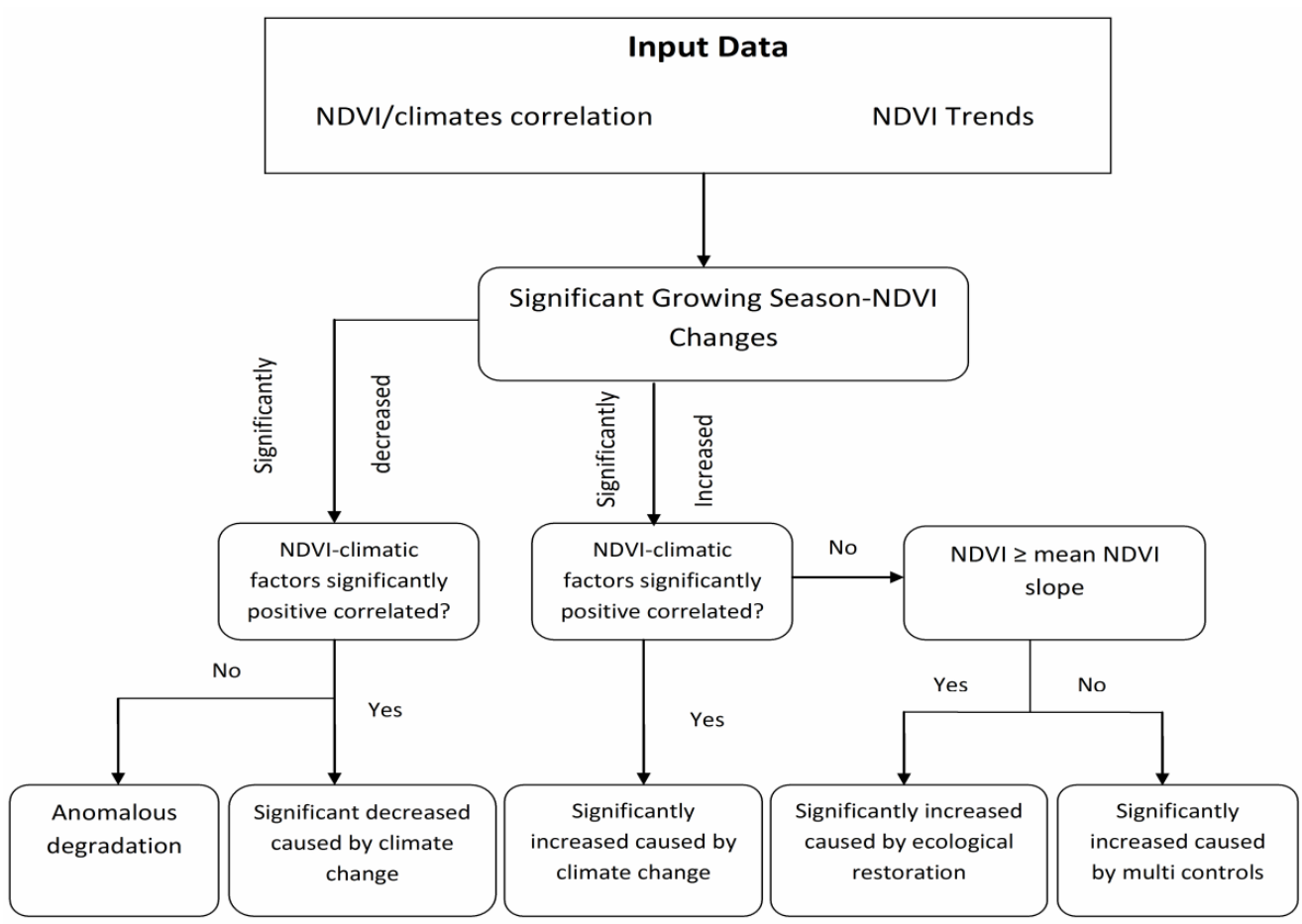

Figure 2: Flow chart showing the algorithm used to identify main driving forces of vegetation change

\section{Results and Discussion}

\section{Temporal Variation of NDVI Trends}

The growing season NDVI in Nepal has significantly increased at the rate of $0.0009 \mathrm{yr}^{-1}$ (Sen's slope $=0.001 \mathrm{yr}^{-1}, p=0.0002$ ) during 1982-2015. The mean NDVI and 
standard deviation found $0.499 \pm 0.014$. The autumn vegetation increased at the rate of $0.001 \mathrm{yr}^{-1}$ (Sen's slope $=0.002 \mathrm{yr}^{-1}, p<0.0001$ ) and the mean NDVI was found to be 0.58 with a high standard deviation. In spring and summer, the NDVI increased at the rate of $0.0008 \mathrm{yr}^{-1}\left(\mathrm{Sen}^{\prime} \mathrm{s}\right.$ slope $\left.=0.0005 \mathrm{yr}^{-1}, \quad p=0.04\right)$ and $0.0004 \mathrm{yr}^{-1}\left(\right.$ Sen $^{\prime} \mathrm{s}$ slope $\left.=0.0003 \mathrm{yr}^{-1}, p=0.23\right)$ respectively. The detailed examination in different periods of growing season from 1982-2015 showed that NDVI increased significantly in the growing season, spring and autumn except during the summer. In summer, the NDVI mean (0.48) and slope $\left(0.0004 \mathrm{yr}^{-1}, p=0.23\right)$ was lower compared with autumn (Table 1).

Table 1: Mann Kendall statistics, mean NDVI, trends and Standard deviation
during growing season in Nepal, 1982-2015

\begin{tabular}{|l|l|l|l|r|l|l|}
\hline Time scale & Linear slope & $\begin{array}{c}\text { Sen's } \\
\text { slope }\end{array}$ & Kendall tau & $p$-value & Inference & Mean $\pm \mathrm{SD}$ \\
\hline $\begin{array}{l}\text { Growing } \\
\text { season }\end{array}$ & $0.0009 \mathrm{yr}^{-1}$ & $0.001 \mathrm{yr}^{-1}$ & 0.44 & 0.0002 & Significant & $0.49 \pm 0.014$ \\
\hline Spring & $0.0008 \mathrm{yr}^{-1}$ & $0.0005 \mathrm{yr}^{-1}$ & 0.24 & 0.04 & Significant & $0.43 \pm 0.02$ \\
\hline Summer & $0.0004 \mathrm{yr}^{-1}$ & $0.0003 \mathrm{yr}^{-1}$ & 0.14 & 0.23 & Insignificant & $\begin{array}{l}0.485 \pm 0.01 \\
8\end{array}$ \\
\hline Autumn & $0.001 \mathrm{yr}^{-1}$ & $0.002 \mathrm{yr}^{-1}$ & 0.52 & $<0.0001$ & Significant & $0.585 \pm 0.25$ \\
\hline
\end{tabular}

The monthly NDVI trend has increased and autumn months have experienced highest mean NDVI of 0.56 and 0.61 with the annual trend of $0.002 \mathrm{yr}^{-1}$ and $0.001 \mathrm{yr}^{-1}$ respectively. The end of the growing season NDVI possesses high mean NDVI compared to the start of the growing season. The mean and NDVI slope during autumn season were relatively higher than those during summer and spring season. Over the past 34 years, there were significant increases in the growing season NDVI. The growing season mean NDVI was relatively higher records in August, September and October, which indicates the plant's phenological change and lengthening of growing season. Similar results of increased NDVI were reported in several parts of the world mainly in the northern hemisphere including China and Tibetan plateau (Peng et al.2011; Pang et al. 2016). Satellite observation showed that China and India are also greening mainly from forest and croplands management (Chen et al. 2019). The lower NDVI during spring season is due to the presence of pre-monsoon drought (Panthi et al. 2017). In summer, excessive moisture (Shrestha 2000; DHM 2015) can worsen the vegetation conditions. High accumulated soil moisture (Quiring and Ganesh 2010), soil water holding capacity (Ji and Peters 2003) and delay response of vegetation to rainfall (Wu et al. 2015) are found to increase greening and more NDVI during autumn. The inter-annual variation of NDVI changes demonstrates that the positive intensity of the vegetation changes was sharply increased after 2005 (Figure 3). 


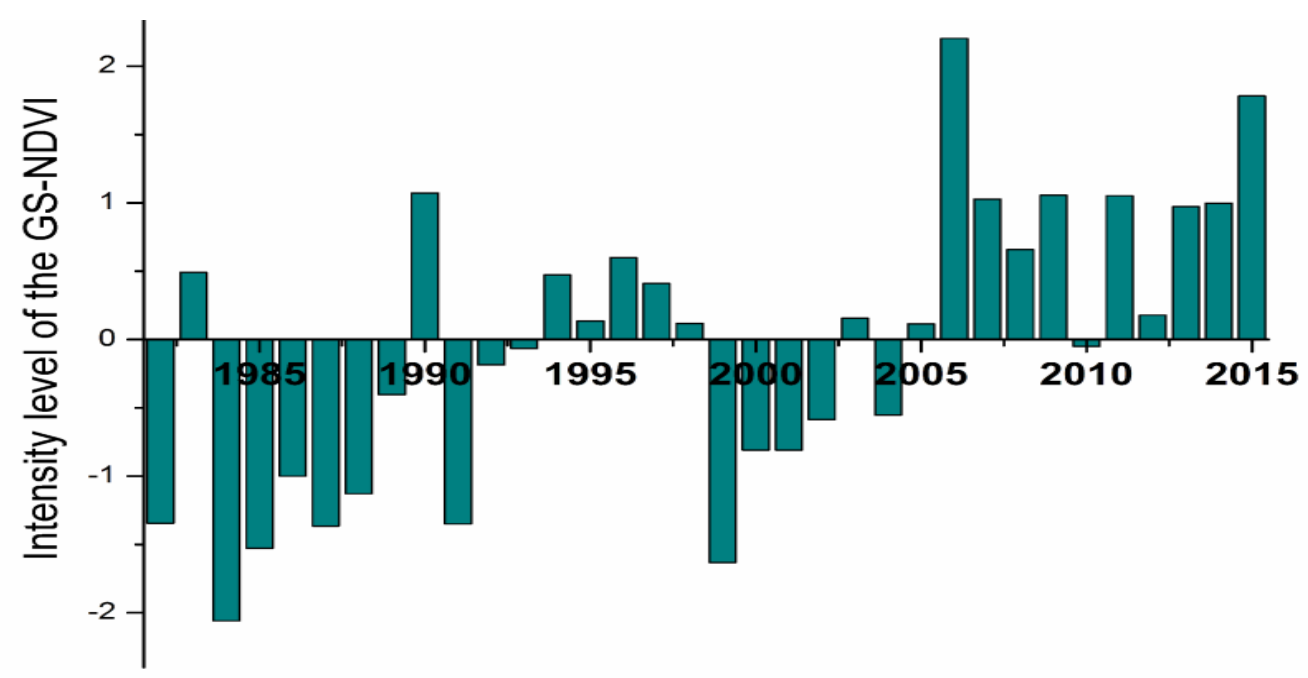

Figure 3: Intensity of the NDVI change during growing season in Nepal, 1982-2015

The intensity of vegetation changes was found $0.065 \mathrm{yr}^{-1}$ during 1982-2015 which was positive but weak $(\sigma(\mathrm{i})<1)$ intensity level. The large positive intensity $(\sigma(\mathrm{i})=2.20)$ of vegetation changes were found in $2006(\sigma(\mathrm{i})>2)$ which was followed by 1990, 2007, 2009, 2011 and 2015 with moderate intensity level $(\sigma(i)>1)$. It also found highest negative intensity level $(\sigma(\mathrm{i})=-2.05)$ in 1984 with moderate negative intensity level $(\sigma(\mathrm{i})>-1)$ in the years of 1982, 1985, 1987, 1988, 1991 and 1999. The large intensity level was found in recent years after 2005. The intensity of vegetation change was highly negative in 1984 but it became positive during 2006 and 2015 (Figure 3). During 2006, ecological drought parameter such as spatially average annual vegetation condition index (VCI) was more than $50 \%$. At the same time, spatially average annual VCI was less than $10 \%$ in annual, pre-monsoon and seasonal monsoon scales in 1984 (Baniya et al. 2019).

\section{Spatial Variation of NDVI Trends}

The highest growing season mean NDVI were mainly found in central hills and eastern Nepal. Generally, the mean NDVI was more than 0.4 in lower and mid hills but it was less than 0.2 to even -1 in northern part (Figure 4a). During 1982-2015, the spatially averaged growing season NDVI was 0.49 with higher (i.e. 0.58) in the autumn season which is followed by the summer, i.e., 0.48. In the spring, the spatially averaged NDVI was 0.43 (Figure $4 \mathrm{~b}$ ). The highest mean NDVI were mainly found in central hills and eastern parts of the country, i.e., more than 0.6 to 0.8 in all the time periods (figure $4 a, 4 b, 4 c \& 5 d$ ). In the spring, very few of the areas in the mid-hills extending from west to east have NDVI between 0.6 and 0.8. Generally, the mean NDVI was less than 0.1 mainly in the Trans-Himalayan region. In low lands, the NDVI was found between 0.1 and 0.2 during spring and summer. In the north, 
the spatially averaged NDVI was sometimes as low as -1 . The growing season NDVI has increased in $84.20 \%$ of the study area (53.08\% significant). A decrease was found in $15.80 \%$ of the areas (3.65\% significant) (Figure 5a). It has significantly increased in large area of the mid hills. The significant change has occurred in $38.11 \%$ during spring which was $27.21 \%$ in summer and $64.09 \%$ in autumn (Figure $5 b, 5 c \& 5 d$ ). The $\mathrm{p}$ value less than 0.05 (red colors in figure 5) represents significant vegetation changes and $\mathrm{p}$ value more than 0.05 (green color in figure 5) represents non significant vegetation changes during 1982-2015.
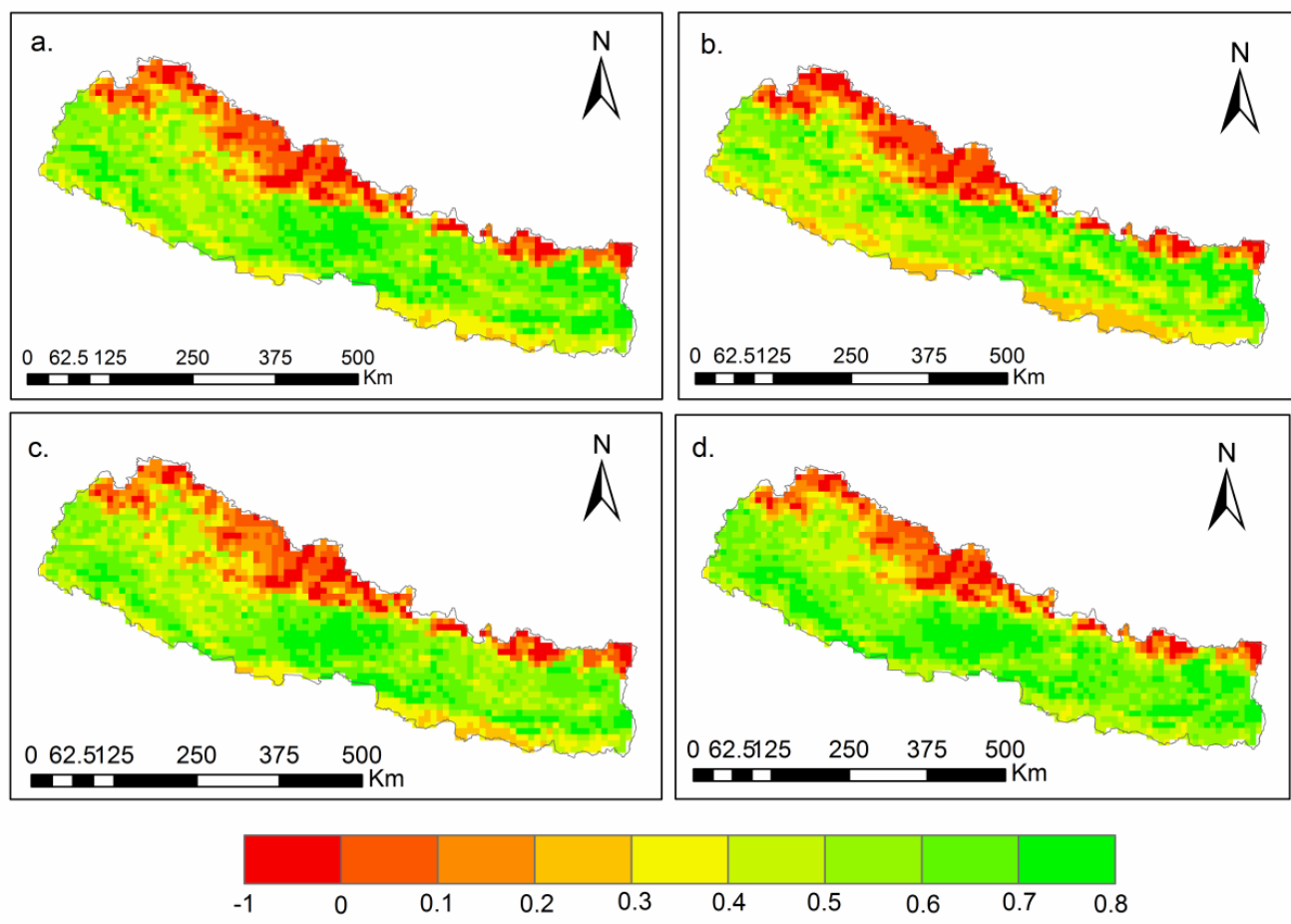

Figure 4: Spatial distribution of the growing season mean NDVI; (a) Growing season (b) Spring (c) Summer and (d) Autumn season during1982-2015 in Nepal 

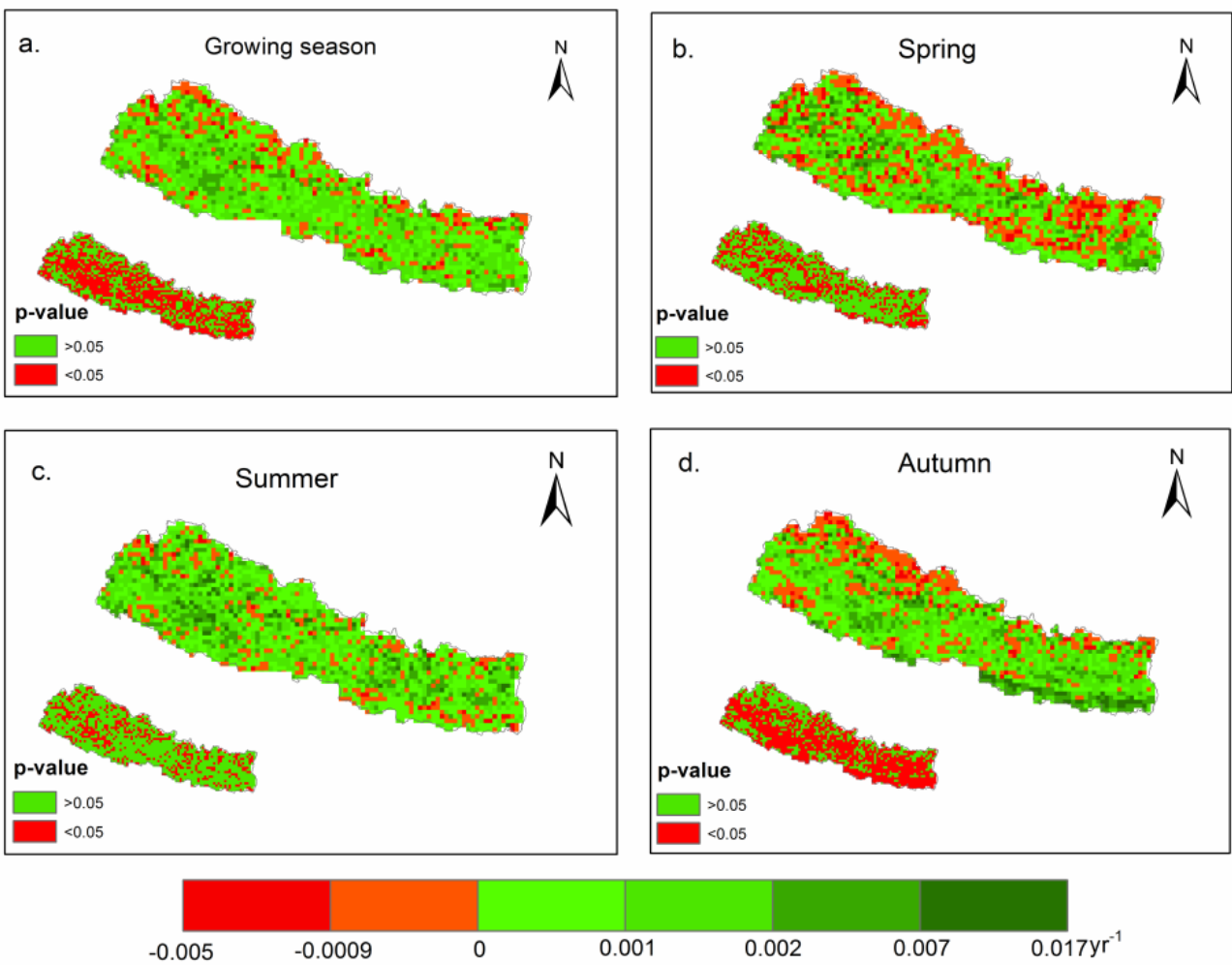

Figure 5: Spatial distribution of the growing season NDVI trends (a) Growing season (b) Spring season (c) Summer season and (d). Autumn season NDVI trend $\left(\mathrm{yr}^{-1}\right)$ during1982-2015 in Nepal

The autumn vegetation has more significant changes especially in mid hills and eastern Terai (Figure 5d). In spring, large areas in the western, northern and mid eastern regions have a negative trend ranging between $0.0009 \mathrm{yr}^{-1}$ to $0.005 \mathrm{yr}^{-1}$ but in summer very few pixels were in decreasing trends compared to the spring and autumn seasons. A high positive NDVI trend of $0.007 \mathrm{yr}^{-1}$ to $0.017 \mathrm{yr}^{-1}$ during summer was found in some parts of the mid-western region. In autumn, NDVI trend increased at the rate of $0.017 \mathrm{yr}^{-1}$ in south eastern parts. The negative trend was marked more during spring season. In general, autumn season contributes more in growing season NDVI. The human encroachment in the forest was very high before 1980s (Sigdyal 1999). Later, the forest increased after an initiation of community forest development programs in 1980s (Poudel et al. 2015). The result of the forest resource assessment carried out between 2010 and 2014 showed that forest cover has increased and has now occupied $40.36 \%$ of the total lands (DFRS 2015). Mostly, the NDVI in forest has more in middle hills than in the southern plains. The middle hill mainly contains temperate broad leaved, mix broad leaved, temperate coniferous (needle-leaved) and subalpine forest. FRA (2010-2014) also found largest coverage of 
forest and shrub land in Nepal (DFRS 2015). Crop lands has increased by $13 \%$ over the past 30 year and the forest land has also increased after 1990s (Paudel et al. 2016).

\section{Growing Season NDVI Changes in Different Altitudes}

The mean NDVI is higher in low lands and lower in high lands. The NDVI distribution was very low above $4200 \mathrm{~m}$ altitude where the mean NDVI was less than 0.2 (Figure 6). Conversely, the mean NDVI was more than 0.4 below $3000 \mathrm{~m}$ altitude in Nepal. In this altitudinal range, the NDVI value was higher during the end of the growing season, i.e., in late summer and autumn season. The timberline and treeline ecotone generally ranging from 3500 to $4200 \mathrm{~m}$ altitude showed good NDVI distribution and positive trends in Nepal (Figure 6). The growing season NDVI trend was mostly positive in low altitude especially after June. The positive trends were also found below 2500m during April. Some of the area in low altitude during May and June experienced negative trend. The highest NDVI trend, i.e., $0.004 \mathrm{yr}^{-1}$ was observed in low altitude during August to October. The mean NDVI was found to be 0.20 in the alpine zone at altitude between 4000 and 5000m where the alpine pasture, dwarf rhododendron scrubs and Juniper scrubs are dominant. The growing season NDVI trends were positive in all bioclimatic zones with a higher NDVI trends in sub-tropical $(1000-2000 \mathrm{~m})$ and tropical regions $(<1000 \mathrm{~m})$.
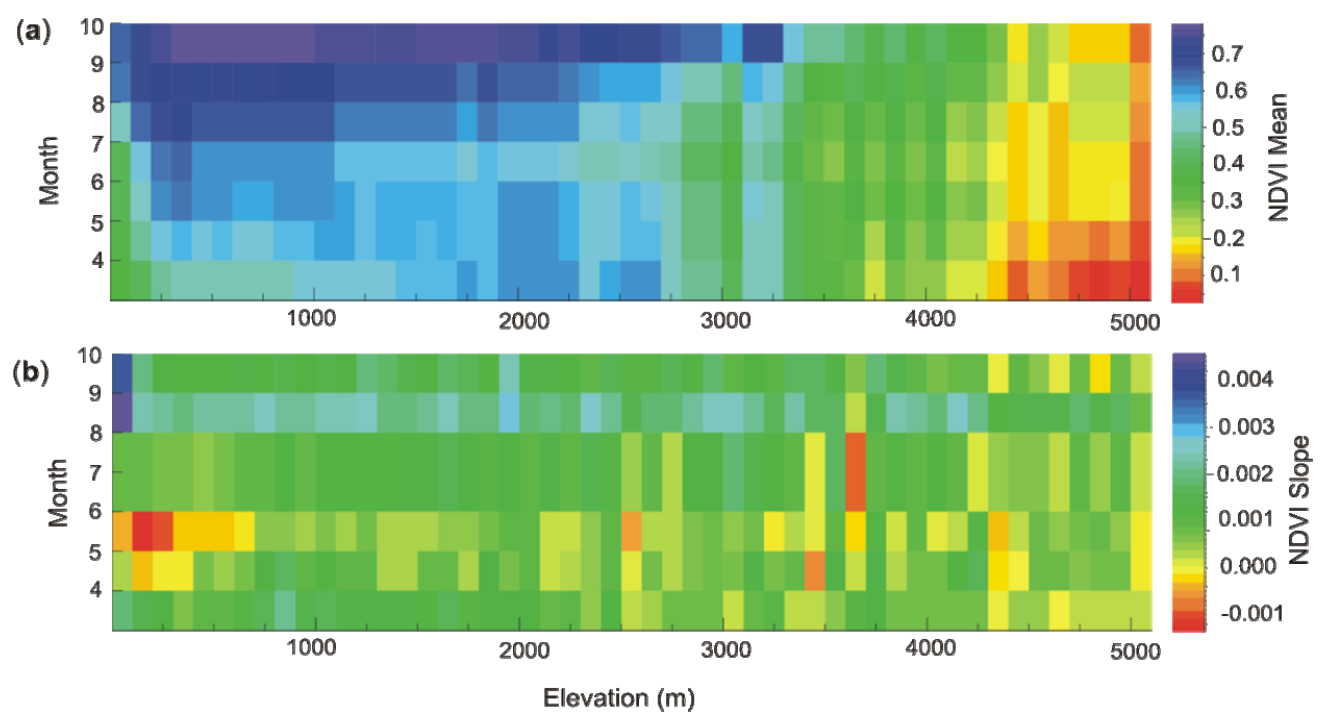

Figure 6: GS-mean NDVI and NDVI trend $\left(\mathrm{yr}^{-1}\right)$ in different altitudinal zone in Nepal, 1982-2015 (each grid in $\mathrm{X}$-axis represents $100 \mathrm{~m}$ altitude and $\mathrm{Y}$-axis represents GS-month from April to October)

The high mean NDVI at the end of growing season indicates plant phenological changes. The treeline ecotone lies between 3300 and $4300 \mathrm{~m}$ altitude (Chhetri and Cairns 2016; Chhetri et al. 2017) showed good NDVI distribution and positive trend. The blue pine trees, Oak trees, Birch-Rhododendron forest, Himalayan fir, Alpine pasture, Trans Himalayan steppe, Juniper species, Eastern Himalaya Oak-Laurel 
evergreen coniferous trees are dominant in the treeline ecotone (MENRIS/ICIMOD 2008). The phenomena of increased vegetation in treeline ecotone were previously investigated using tree ring records (Gaire et al. 2014; Gaire et al. 2017b; Tiwari et al. 2017a; Sigdel et al. 2018). Our remote sense based results corroborate the previous findings. The low regions are plain and cultivate more crops and have a dense tropical forest during growing season that could reflect more NDVI in the tropical and sub-tropical regions in Nepal. The areas above 5000m altitude are low human disturbed area where the agriculture is not practiced and there is not any vegetation. Therefore, it possesses 0.2 to -1 mean NDVI (Figure 4).

\section{Driving Forces of GS-NDVI Dynamics during 1982-2015}

During growing season, $58.64 \%$ of the areas have significant vegetation changes in which $54.78 \%$ of the areas have significant positive and $3.85 \%$ of the areas have significant negative changes. There were several factors that contributed to these vegetation changes which were computed based on pixelwise correlation between NDVI and climates (i.e. temperature and precipitation) and threshold NDVI dynamics. The correlation between NDVI and temperature was significantly positive $(\mathrm{r}=0.33, \mathrm{p}<0.05)$ but the correlation between NDVI and precipitation was significantly negative $(\mathrm{r}=0.41, \mathrm{p}=0.02)$ during $1982-2015$. The growing season NDVI significantly increased (Sen's slope $=0.001 \mathrm{yr}^{-1}, \mathrm{p}=0.0002$ ) in Nepal during 19822015. In between 1994 and 2005, the annual NDVI graphs showed decrease during growing season, spring and autumn, may be due to natural and human induced disasters. But, after 2000, it again picked up and sharply increased. At the same time from 1982 to 2015, the growing season temperature has increased with an average warming trend of $0.03^{\circ} \mathrm{Cyr}^{-1}\left(\mathrm{R}^{2}=0.392, \mathrm{p}=0.0002\right)$ but precipitation decreased at the rate of $2.76 \mathrm{~mm} \mathrm{yr}^{-1}\left(\mathrm{R}^{2}=0.027, \mathrm{p}=0.20\right)$. The precipitation has mainly decreased after 2000 when the temperature and NDVI showed increasing trends (Figure 7). The detailed pattern of temperature, precipitation and NDVI changes during last 34 years in between 1982-2000 and 2000-2015 in overall growing season and its different time periods are presented in Figure $7 \& 8$.

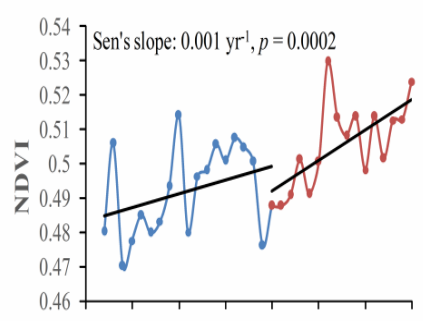

19801985199019952000200520102015 Year

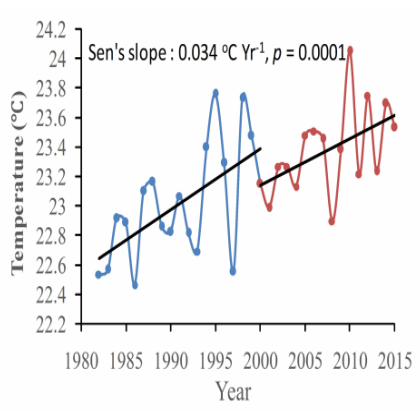

Year

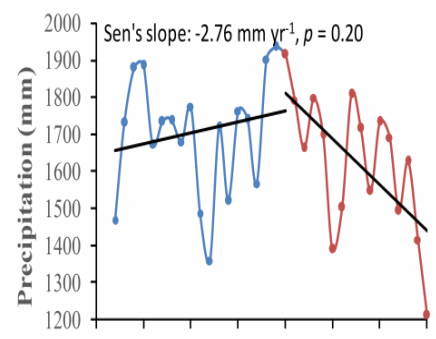

19801985199019952000200520102015

Year

Figure 7: NDVI, temperature and precipitation trends based on MK test and Sen's slope in overall growing season during 1982-2015 in Nepal 

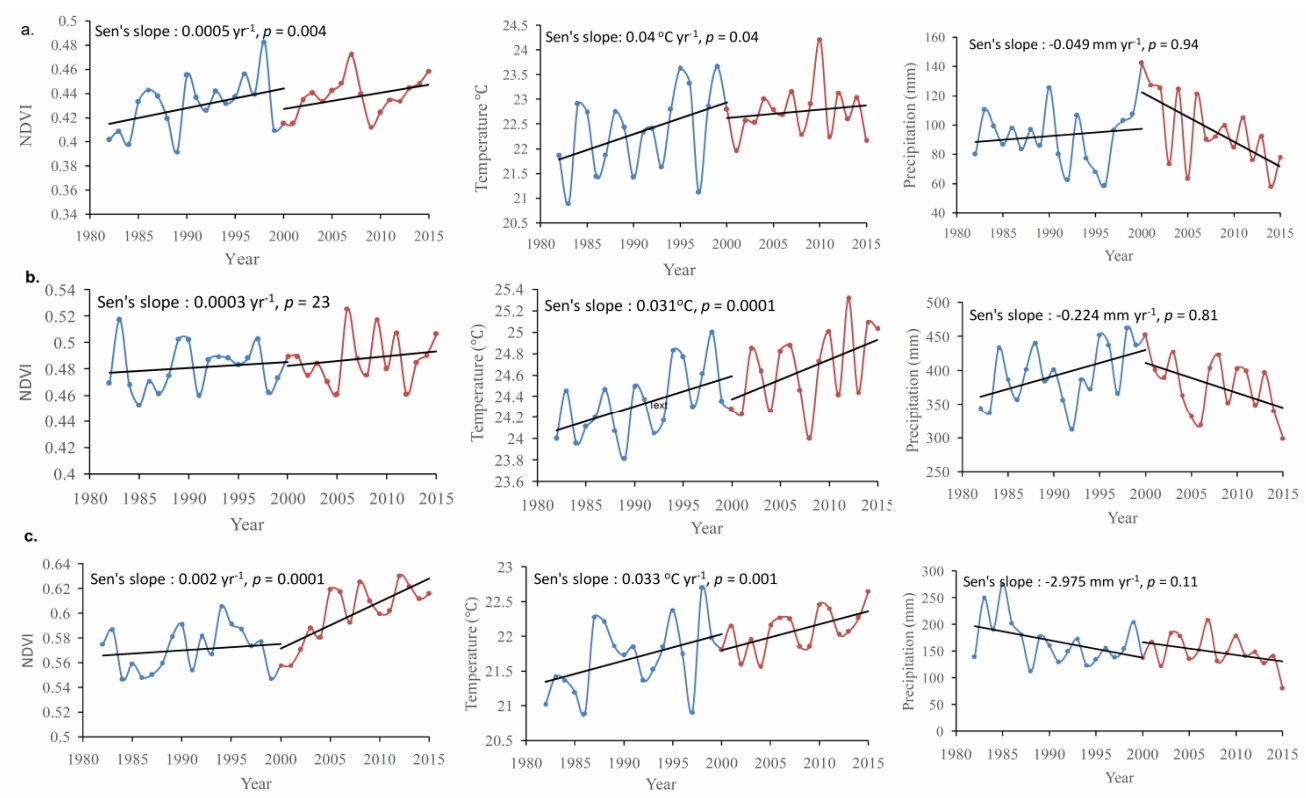

Figure 8: NDVI, temperature and precipitation trends based on MK test and Sen's slope in (a) Spring; (b) Summer and (c) Autumn season during 1982-2015 in Nepal

In the summer, the mean NDVI was found to be 0.48 and the annual trend was positive but insignificant (Figure $8 \mathrm{~b}$ ). The mean NDVI during autumn was found to be 0.58 , which is higher than the spring and summer. During autumn, the vegetation increased at an average rate of $0.002 \mathrm{yr}^{-1}(p<0.0001)$, which sharply increased after 2000 (Figure 8c). The temperature increased by $0.03^{\circ} \mathrm{Cyr}^{-1}$ in both summer and autumn season. In summer, the precipitation was positive until 2000; afterward it sharply decreased. In spring, the average temperature trend was relatively higher $\left(0.04^{\circ} \mathrm{Cyr}^{-1}\right)$ and exhibited similar trends with NDVI but reverse with precipitation. The temperature and NDVI exhibited positive trend and coincided well with one another in which the temperature and NDVI increased significantly in all the growing season time periods except in the summer. On the contrary, the precipitation decreased in all the growing season mainly after 2000. The autumn rains have decreased by $2.97 \mathrm{~mm} \mathrm{yr}^{-1}$ since the beginning of the study period. The overall trends showed that temperature and NDVI increased but precipitation decreased. The NDVI was positively correlated with temperature and the correlation was stronger than that with a precipitation. The detailed vegetation changes and relevant factors are presented in Figure 9. The red color in these figures show significant vegetation changes, i.e., the left inset Figure 9 (a) shows significant positive change, right inset Figure 9 (c) shows significant negative changes and the middle Figure 9(b) shows total significant vegetation changes during last 34 years. The result showed that $39.62 \%$ of the areas have positive changes and they are significantly correlated in between NDVI and temperature. Similarly, ecological restoration was responsible for $25.16 \%$ positive vegetation changes. 


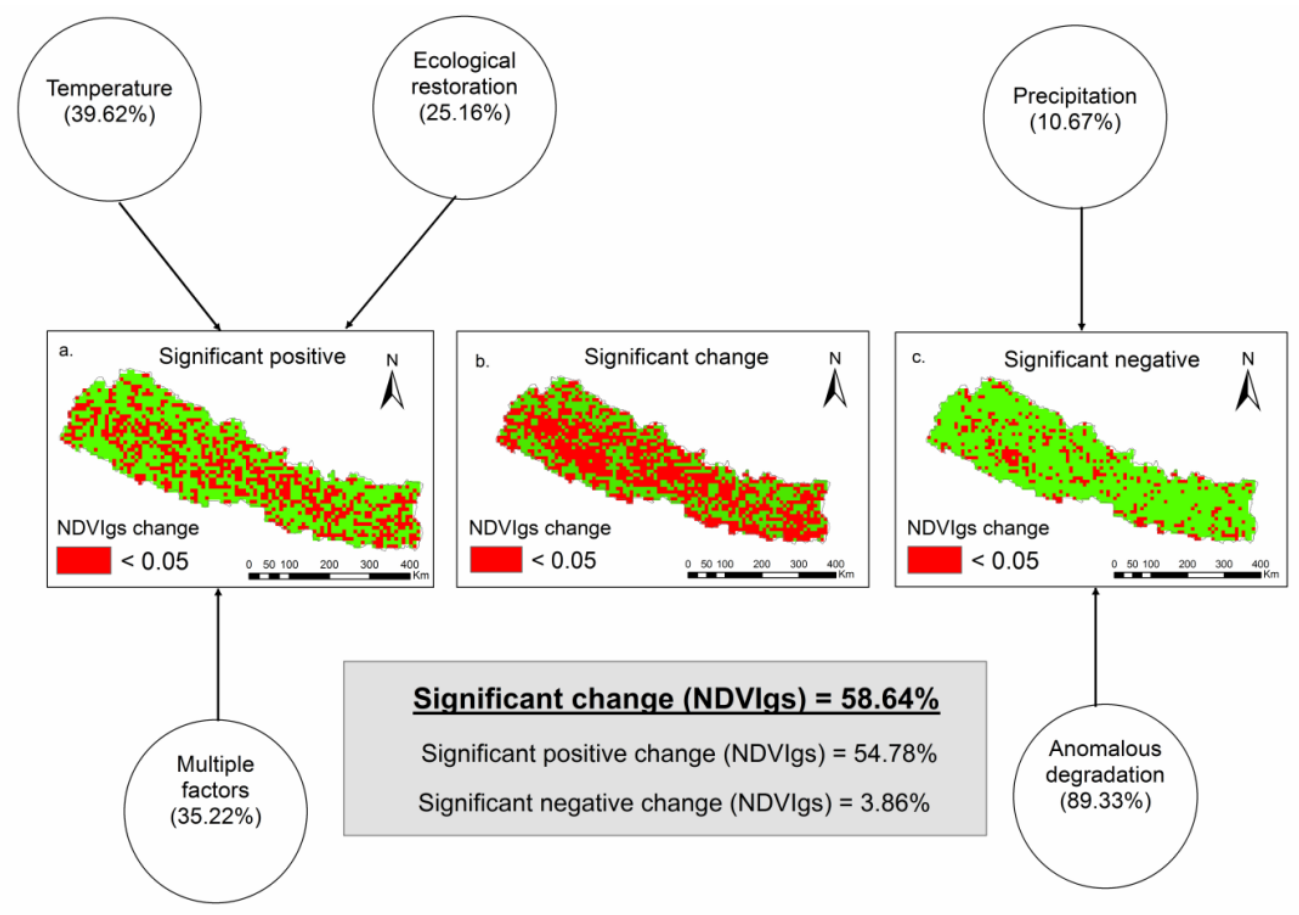

Figure 9: Growing season vegetation changes and their relevant driving forces during 1982-2015 in Nepal

The ecological restoration represented re-forestation, greenery developments and improved agricultural practices. Beside these factors, multiple factors have contributed $35.22 \%$ to significant vegetation changes. Those multiple factors could be physical, biological and socio-cultural factors. The multiple factors except temperature and ecological restoration can include several environmental factors such as edaphic (parent materials, soil), geographic (gravity, rotational effects, geographic position, volcanism, diastrophism, erosion and deposition, topography), pyric (fire) and biotic (plants competition, animals and man) (Billings 1952). Meanwhile, very few of the areas have found significantly decreased NDVI which was related with decreased trends of precipitation and anomalous degradation, i.e., human activities. Anomalous degradation (human activities) has contributed $89.33 \%$ to decreased $3.86 \%$ vegetation which could be deforestation, land use land cover changes, overgrazing on grasslands, poor agricultural practices and less ecological restoration on those particular areas. Beyond the climatic controls, vegetation types, altitude, human activities and ecological restoration also have contributed to vegetation dynamics in Nepal. The result explored by (Chhetri et al. 2017) in Nepal Himalaya showed that topography and human disturbance are the main controlling factor. In China, land use change was determined as the dominant factor that drives vegetation greenness (Hua et al. 2017) during 1981-2011. Some of the previous studies in Nepal also showed positive NDVI trends which were mainly attributed to 
increased $\mathrm{CO}_{2}$ level (Krakauer et al. 2017) and temperature (Baniya et al. 2018) but we present only growing season NDVI changes and associated factors. In our study, the temperature was determined to be the largest contributor to growing season vegetation change compared with precipitation and followed by ecological restoration and multiple environmental factors.

\section{Conclusion}

The study provides a detailed examination of growing season vegetation change and explored their driving forces during last three decades in Nepal. We found positive intensity of growing season vegetation changes with more NDVI below $3000 \mathrm{~m}$ altitude mainly during late summer and autumn. The large intensity of vegetation changes was found after 2005. NDVI was significantly increased in overall growing season, spring and autumn but insignificantly increased in summer season. At the same time period, the growing season temperature was significantly increased but precipitation decreased. The presence of higher mean NDVI and NDVI trends during autumn indicate lengthening of growing season in Nepal. The higher mean NDVI and positive changes at the tree line ecotone also corroborate good regeneration of plants and possible shifting towards higher mountain. During growing season, large areas had a significant positive correlation with temperature and significant negative correlation with precipitation. It was found that temperature was determined to be the largest contributor to growing season vegetation change compared with precipitation and followed by ecological restoration and multiple environmental factors. The results of this study could have enormous scientific value and good reference among scientific communities in vegetation change investigation in Nepal. However, fine resolute satellite and in-situ ecological data sets at large temporal and spatial scales are recommended for comprehensive finding of vegetation changes in the future.

\section{Acknowledgement}

National Natural Science Foundation of China (Grant Nos. 41790424, 41730645 and 41425002) and Chinese Academy of Sciences are the part of this research. We would like to express sincere gratitude to the NOAA GIMMS team for NDVI data and Department of Hydrology and Meteorology (DHM), Nepal. We are thankful to the Institute of Science and Technology (IoST), Tribhuvan University (TU), Nepal.

\section{Literature Cited}

Baniya, B., Q. Tang, Z. Huang, S. Sun, K-A. Techato. 2018. Spatial and Temporal Variation of NDVI in Response to Climate Change and the implication for Carbon Dynamics in Nepal. Forest 9:329. doi:https://doi.org/10.3390/f9060329.

Baniya, B., Q. Tang, X. Xu, GG. Haile, G. Chhipi-Shrestha. 2019. Spatial and temporal variation of drought based on satellite derived vegetation condition index in Nepal from 1982-2015.Sensors:430. doi:10.3390/s19020430. 
Bonan, GB. 2008. Forests and Climate Change: Forcings, Feedbacks, and the Climate Benefits of Forests. Science 320:1444.

Billings, WD. 1952. The environment complex in relation to plant growth and distribution.Quarterly review of Biology, pp 251-265.

CBS. 2011. Population Monograph of Nepal, National Planning Commission Secretariat, Central Bureau of Statistics (CBS), Government of Nepal Population Dynamics.

Chen, C., T. Park, X. Wang, S. Piao, B. Xu, R. Chaturvedi, R. Fuchs, V. Brovkin, P. Ciais, R. Fensholt, H. Tommervik, G. Bala, Z. Zhu, RR. Nemani, RB Myneni. 2019. China and India lead in greening of the world through land-use management. Nature Sustainability 2:122-129. doi:10.1038/s41893-019-0220-7.

Chhetri, P. K., D. M. Cairns. 2016. Dendroclimatic response of Abies spectabilis at treeline ecotone of Barun Valley, eastern Nepal Himalaya. Journal of Forestry Research 27:1163-1170. doi:10.1007/s11676-016-0249-7.

Chhetri, P. K., K. B. Shrestha, D. M. Cairns. 2017. Topography and human disturbances are major controlling factors in treeline pattern at Barun and Manang area in the Nepal Himalaya. Journal of Mountain Science 14:119-127. doi:10.1007/s11629-016-4198-6.

Craine, J. M., M. W. Elizabeth, E. G. Towne, S. W. Kembel. 2011. Flowering phenology as a functional traits in a tall grass prairie. New Phytologist 193:673682. doi:10.1111/j.1469-8137.2011.03953.x.

DFRS. 2015. State of Nepal's Forests, Forest Resource Assessment (FRA) Nepal, Department of Forest Research and Survey (DFRS), Kathmandu, Nepal.

DHM. 2015. Study of climate and climatic variation over Nepal, Department of Hydrology and Meteorology (DHM), Kathmandu, Nepal.

Ding, Y. H., G. Y. Ren, ZC. Zhao, Y. Xu, Y. Luo, QP. Li, J. Zhang. 2007. Detection, causes and projection of climate change over China: An overview of recent progress. Advances in Atmospheric Sciences 24:954-971; doi:10.1007/s00376-0070954-4.

Dobremez, J. F. 1976. Le Nepal Ecolgie et Biogeography (Ecology and Biogeography of Nepal), Editions du Centre National de la Researche Centifique, Paris, France.

DoFRS. 2017. Forest and watershed profile of local level (744) structures of Nepal, Department of Forest Research and Survey (DoFRS),Kathmandu, Nepal.

Fensholt, R., S. R. Proud. 2012. Evaluation of Earth Observation based global long term vegetation trends -Comparing GIMMS and MODIS global NDVI time series. Remote Sensing of Environment 119:131-147.

doi:https://doi.org/10.1016/j.rse.2011.12.015

Gaire, N. P., D. R. Bhuju, M. Koirala, S. K. Shah, M. Carrer, R. Timilsena. 2017a. Treering based spring precipitation reconstruction in western Nepal Himalaya 
since AD 1840. Dendrochronologia 42:21-30.

doi:https://doi.org/10.1016/j.dendro.2016.12.004.

Gaire, N. P, M. Koirala, D. R. Bhuju, HP. Borgaonkar. 2014. Treeline dynamics with climate change at the central Nepal Himalaya. Climate of the Past 10:1277-1290. doi:10.5194/cp-10-1277-2014.

Gaire, N. P., Koirala, M., Bhuju, D. R., Carrer, M. 2017b. Site- and species-specific treeline responses to climatic variability in eastern Nepal Himalaya. Dendrochronologia 41:44-56. doi:https:/ / doi.org/10.1016/j.dendro.2016.03.001.

Gilbert, R. O. 1987. Statistical Methods for Environmental Pollution Monitoring;van Nostrand Reinhold Company: New Work, NY, USA.320.

Hirsch, R. M., J. R. Slack, R. A. Smith. 1982. Techniques of trend analysis for monthly water quality data. Water Resource Research. doi:10.1029/WRO18i001p00107.

Holben, B. N. 1986. Characteristics of Maximum Value Composite (MVC) images from temporal AVHRR data. International Journal of Remote Sensing 7:14171434. doi:10.1080/01431168608948945.

Hua, W. J., H. Chen, L. Zhou, Z. Xie, M. Qin, X. Li, H. Ma, Q. Huang, S. Sun. 2017. Observational Quantification of Climatic and Human Influences on Vegetation Greening in China. Remote Sensing 9. doi:10.3390/rs9050425.

IPCC. 2007. Climate Change: Impacts, adaptation and vulnerability, Working Group II Contribution to the Fourth Assessment Report of the Intergovernmental Panel on Climate Change,. Cambridge University Press.

Jeong, SJ., CH. Ho, JH. Jeong. 2009. Increase in vegetation greenness and decrease inspring time warming over east Asia. Geophysical Research Letters, Vol 36, L02710, doi:10.1029/2008GL036583.

Jeong, S. J., CH. Ho, TW.Park, J. Kim, S. Levis. 2011. Impact of vegetation feedback on the temperature and its diurnal range over the Northern Hemisphere during summer in a 2 x CO2 climate. Climate Dynamics 37:821-833. doi:10.1007/s00382-010-0827-x.

Jiang, L. L., G. Jiapaer, A. M. Bao, H. Guo, F. Ndayisaba. 2017. Vegetation dynamics and responses to climate change and human activities in Central Asia. Science of the Total Environment 599:967-980. doi:10.1016/j.scitotenv.2017.05.012.

Ji, L., AJ. Peters. 2003. Assessing vegetation response to drought in the northern Great Plains using vegetation and drought indices.Remote Sens Environ :87, 8598. doi:10.1016/S0034-4257(330 03)00174-3.

Karki, R., S. Hasson, U. Schickhoff, T. Scholten, J. Bohner. 2017. Rising Precipitation Extremes across Nepal. Climate,5, 4. doi:10.3390/cli5010004.

Kendall, M. G. 1975. Rank correlation methods, $4^{\text {th }}$ edition, Charles Griffin, London, UK 
Kharal, D. K., U. K. Thapa, S. St George, H. Meilby, S. Rayamajhi, D. R. Bhuju. 2017. Tree-climate relations along an elevational transect in Manang Valley, central Nepal. Dendrochronologia 41:57-64. doi:10.1016/j.dendro.2016.04.004.

Krakauer, N. Y., T. Lakhankar, J. D. Anadon. 2017. Mapping and Attributing Normalized Difference Vegetation Index Trends for Nepal. Remote Sensing 9, 986. doi:10.3390/rs9100986.

Liu, XF., XF. Zhu, SS. Li, YX. Liu, YZ. Pan. 2015. Changes in Growing Season Vegetation and Their Associated Driving Forces in China during 2001-2012. Remote Sensing 7:15517-15535. doi:10.3390/rs71115517.

Lotsch, A., M. A. Friedl, BT Anderson, CJ. Tucker. 2005. Response of terrestrial ecosystems to recent Northern Hemispheric drought. Geophysical Research Letters 32. doi:10.1029/2004gl022043.

LRMP. 1986. Land Resources Mapping Project, Survey Department. HMGN and Kenting Earth Sciences, Kathmandu, Nepal.

Mann, H. B. 1945. Nonparametric tests against trend. Econometrica 13:245-259.

MENRIS/ICIMOD. 2008. Ecology of Nepal, Digital polygon data of ecology (elevation and vegetation zones) of Nepal, Mountain Environment Regional Information System (MENRIS), ICIMOD.

Myneni, R. B., C. D. Keeling, C. J. Tucker, G. Asrar, R. R. Nemani. 1997. Increased plant growth in the northern high latitudes from 1981 to 1991. Nature 386:698702. doi:10.1038/386698a0.

Oliver, M. A., W. R. Kriging 1990. A method of interpolation for geographical information systems. Internation Journal of Geographical Information System:313332

Pang, GJ., XJ. Wang, M. X. Yang. 2016. Using the NDVI to identify variations in, and responses of, vegetation to climate change on the Tibetan Plateau from 1982 to 2012. Quaternary International 444:87-96. doi:10.1016/j.quaint.2016.08.038.

Panthi, S., A. Brauning, Z. K. Zhou, Z. X. Fan. 2017. Tree rings reveal recent intensified spring drought in the central Himalaya, Nepal. Global and Planetary Change 157:26-34. doi:10.1016/j.gloplacha.2017.08.012.

Park, HS., BJ. Sohn. 2010. Recent trends in changes of vegetation over East Asia coupled with temperature and rainfall variations. Journal of Geophysical Research-Atmospheres 115. doi:10.1029/2009jd012752.

Paudel, B., J. Gao, Y. Zhang, X. Wu, S. Li, J. Yan. 2016. Changes in Cropland Status and Their Driving factors in the Koshi River Basin of the central Himalayas, Nepal.Sustainability8,933. doi:10.3390/su8090933.

Peng, S., A. Chen, L. Xu, C. Cao, J. Fang, RB.Myneni, JE. Pinzon, CJ. Tucker, S. Piao. 2011.Recent change of vegetation growth trend in China. Environmental Research Letters.6:044027(044013 pp). doi:10.1088/1748-9326/6/4/044027. 
Pettorelli, N., JO. Vik, A. Mysterud, JM. Gaillard, CJ. Tucker, NC. Stenseth. 2005.Using the satellite-derived NDVI to assess ecological responses to environmental change. Trends in Ecology $\mathcal{E}$ Evolution 20:503-510. doi:10.1016/j.tree.2005.05.011.

Piao, S. L., J. Y. Fang, L. M. Zhou, P. Ciais, B. Zhu, B. 2006. Variations in satellitederived phenology in China's temperate vegetation. Global Change Biology 12:672-685. doi:10.1111/j.1365-2486.2006.01123.x.

Piao, S. L., X. H. Wang, P. Ciais, B. Zhu, T. Wang, J. Liu. 2011. Changes in satellitederived vegetation growth trend in temperate and boreal Eurasia from 1982 to 2006. Global Change Biology 17:3228-3239. doi:10.1111/j.1365-2486.2011.02419.x.

Poudel, N. R., N. Fuwa, K. Otsuka. 2015. The impact of community forestry program on forest conditions,management intensity and revenue generation in the dang district of Nepal. Environment and Development Economics 20:259-289.

Quiring, S. M., S. Ganesh. 2010. Evaluating the utility of the Vegetation Condition Index (VCI) for monitoring meteorological drought in Texas, Agric For Meteorol330-339. doi:10.1016/j.agrformet.2009.11.015, 2010.

Schaefer, K., A. S. Denning, O. Leonard. 2005. The winter Arctic Oscillation, the timing of spring, and carbon fluxes in the Northern Hemisphere. Global Biogeochemical Cycles 19, GB3017. doi:10.1029/2004gb002336.

Schut, A. G. T., E. Ivits, J. G. Conijn, B. Brink, R. Fensholt. 2015. Trends in Global vegetation Activity and Climatic Drivers Indicates a Decoupled Response to Climate Change. PLOS ONE10 (10): e0138013. doi:10.1371/journal.pone.0138013.

Sen, P. K. 1968. Estimates of the regression coefficient based on Kendall's tau. Journal of the American Statistical Association 63(324). doi:10.1080/01621459.1968.10480934.

Shen, M., S. Piao, N. Cong, G. Zhang, I. A. Jassens. 2015. Precipitation impacts on vegetation spring phenology on the Tibetan Plateau. Global Change Biology 21:3647-3656. doi:10.1111/gcb.12961.

Shrestha, K. B., P. K. Chhetri, R. Bista. 2017. Growth responses of Abies spectabilis to climate variations along an elevational gradient in Langtang National Park in the central Himalaya, Nepal. Journal of Forest Research 22:274-281. doi:10.1080/13416979.2017.1351508.

Shrestha, M. L. 2000. Interannual variation of summer monsoon rainfall over Nepal and its relation to Southern Oscillation Index. Meteorology and Atmospheric Physics 75:21-28. doi:10.1007/s007030070012.

Sigdyal, K. P.1999. Save ecological balance: environment problems and their solution in Nepal, Nepal Nature's Paradise; Insight in to diverse facets of Topography, Flora and ecology. 
Sigdel, S. R., Y. Wang, JJ. Camarero, H. Zhu, E. Liang, J. Penuelas. 2018. Moisturemediated responsiveness of treeline shifts to global warming in the Himalayas. Global Change Biology. doi:10.1111/gcb.14428.

Stibig, H. J., A. S. Belward, P. S. Roy, U. R. Wasrin, R. Agrawal, PK. Joshi, Hildanus, R. Beuchle, S. Fritz, S. Mubareka, C. Giri.2007. A land-cover map for South and Southeast Asia derived from SPOT-VEGETATION data. Journal of Biogeography 34:625-637. doi:10.1111/j.1365-2699.2006.01637.x.

Sun, J., XJ. Qin. 2016. Precipitation and temperature regulate the seasonal changes of NDVI across the Tibetan Plateau. Environmental Earth Sciences 75:291. doi:10.1007/s12665-015-5177-x.

Thapa, U. K., S. St George, D. K. Kharal, N. P. Gaire.2017. Tree growth across the Nepal Himalaya during the last four centuries. Progress in Physical Geography 41:478-495. doi:10.1177/0309133317714247.

Tian, HJ., CX. Cao, W. Chen, SN.Bao, B. Yang, RB. Myneni. 2015. Response of vegetation activity dynamic to climatic change and ecological restoration programs in Inner Mongolia from 2000 to 2012. Ecological Engineering 82:276289; doi:10.1016/j.ecoleng.2015.04.098.

Tiwari, A., Z. X. Fan, A. S. Jump, SF. Li, Z. K. Zhou. 2017a. Gradual expansion of moisture sensitive Abies spectabilis forest in the Trans-Himalayan zone of central Nepal associated with climate change. Dendrochronologia 41:34-43. doi:10.1016/j.dendro.2016.01.006.

Tiwari, A., Z. X. Fan, A. S. Jump, ZK. Zhou. 2017b. Warming induced growth decline of Himalayan birch at its lower range edge in a semi-arid region of TransHimalaya, central Nepal. Plant Ecology 218:621-633. doi:10.1007/s11258-0170716-z.

Uddin, K., H. L. Shrestha, MSR. Murthy, B. Bajracharya, B. Shrestha, H. Gilani. 2015. Development of 2010 national land cover database for the Nepal. Journal of Environmental Management 148:82-90. doi:10.1016/j.jenvman.2014.07.047.

Vitasse, Y., C. Francois, N. Delpierre, E. Dufrene, A. Kremer, I. Chuine, S. Delzon. 2011. Assessing the effects of climate change on the phenology of European temperate trees. Agricultural and Forest Meteorology 151:969-980. doi:10.1016/j.agrformet.2011.03.003.

Walther, G. R., E. Post, P. Convey, A. Menzel, C. Parmesank, TJC. Beebee, JM. Fromentin, OH. Guldberg, F. Bairlein.2002. Ecological responses to recent climate change. Nature 416:389-395.

Wang, X. H., Piao, SL., Ciais, P., Li, JS., Friedlingstein, P., Koven, C., Chen, AP. 2011. Spring temperature change and its implication in the change of vegetation growth in North America from 1982 to 2006. Proceedings of the National Academy of Sciences of the United States of America 108:1240-1245. doi:10.1073/pnas.1014425108. 
Wang, X. Y., T. Wang, D. Liu, H. Guo, HB. Huang, YT. Zhao. 2017. Moisture-induced greening of the South Asia over the past three decades. Global Change Biology 23:4995-5005 doi:10.1111/gcb.13762.

Wu, D. H., X. Zhao, SL. Liang, T. Zhou, KC. Huang, BJ. Tang, WQ. Zhao. 2015. Timelag effects of global vegetation responses to climate change. Global Change Biology 21:3520-3531. doi:10.1111/gcb.12945.

Xu, XT., SL. Piao, XH. Wang, AP. Chen, P. Ciais, RB. Myneni. 2015. Spatio-temporal patterns of the area experiencing negative vegetation growth anomalies in China over the last three decades. Environmental Research Letters 7. doi:10.1088/1748-9326/7/3/035701.

Zhang, G., X. Xu, C. Zhou, H. Zhang, H. Ouyang. 2011. Response of grassland vegetation to climate variations on different temporal scales in Hulun Buir grasslands in the past 30 years. Journal of Geographical Sciences 21(4):634-650.

Zhang, Y. L., JG. Gao, L. S. Liu, Z. F. Wang, M. J. Ding, XC. Yang. 2013. NDVI-based vegetation changes and their responses to climate change from 1982 to 2011: A case study in the Koshi River Basin in the middle Himalayas. Global and Planetary Change 108:139-148. doi:10.1016/j.gloplacha.2013.06.012.

Zhou, L. M., C. J. Tucker, RK. Kaufmann, D. Slayback, NV. Shabanov, RB. Myneni. 2001. Variations in northern vegetation activity inferred from satellite data of vegetation index during 1981 to 1999. Journal of Geophysical ResearchAtmospheres 106:20069-20083. doi:10.1029/2000jd000115.

Zhu, Z. C., S. Piao, RB. Myneni. et al. 2016. Greening of the Earth and its drivers. Nature Climate Change. 6:791. doi:10.1038/nclimate3004. 